\title{
Attack Under Load of Tempered Tar/Pitch-Bonded Egyptian Dolomite by BOF Slag
}

\author{
転炉スラグに接したタール/ピッチで結合強化したドロマイト耐火物の荷重下耐久性
}

\author{
Emad Mohamed M. EWAIS, Azza Mohamed AHMED, Abo-Al-KASEM* and Abd-Ruhman El-SHERIF* \\ Central Metallurgical Research \& Development Institute (CMRDI), Helwan, Cairo, Egypt \\ * Researches Sector, Egyptian Iron and Steel Company, Helwan, Egypt
}

\begin{abstract}
Different tar/pitch bonded Egyptian dolomite and dolomite-magnesite mixtures with magnesia content ranging between $30-50 \%$ to replace dolomite, were prepared. Three different types of tars with different pitch content (I, II and III) were used. The mixtures were moulded, tempered and attacked by BOF slag at temperatures up to $1700^{\circ} \mathrm{C}$. The attacking process was carried out under load $3.5-5 \mathrm{~kg} / \mathrm{cm}^{2}$ as a new method to study the deformation of the refractory to indicate the slag attack. The results showed that tar/pitch (III) with $80 \%$ pitch can resist load up to $4 \mathrm{~kg} / \mathrm{cm}^{2}$ when attacked by BOF slag. At the same time, increasing the magnesia content of the tar/pitch (III)-bonded dolomite up to $50 \%$ magnesia can increase its softening under load up to $5 \mathrm{~kg} / \mathrm{cm}^{2}$. The effect of the slag composition on the best-obtained mixture of the tar/pitch (III)-bonded dolomite-magnesite refractory was studied. Tempered tar/pitch (III)-bonded Egyptian dolomite was attacked by synthetic basic slag containing different iron oxide content. It was found that the increase of the iron oxide content of the slag is the main factor responsible for the attacking of refractories. It was concluded from this study that, this test could be considered as beneficial test because it simulates the application of the refractories in the furnace. It also can be used as fast criteria for the determination of the resistance of the refractories for slag attacking and can provide the manufacturer and the consumer valuable data about the behavior under load.

[Received July 1, 2002; Accepted August 9, 2002]
\end{abstract}

Key-words : Attack under load, Tar/pitch, Dolomite, Magnesia, BOF slag

\section{Introduction}

Metallurgical and economical advantages have favoured the utilization of dolomite refractories in the steel production and hence steel producing furnaces are the majors consuming centers of dolomite refractories. In steel industry, application of unfired dolomite refractories is mainly confined to the lining of BOF converters, BOF ladies ladle furnaces, VD/VAD/VOD/AOD vessels and electric arc furnaces. ${ }^{1-9)}$ The specific consumption of dolomite bricks varies from plant to plant due to varying steel temperature, slag composition, tap to tap time, nature of flux used, etc. An improvement has been made in such bricks in which carbonaceous material such as pitch, tar and/or flake or vein graphite were used to form the bond of dolomite-carbon bricks. ${ }^{10)-16)}$

Although refractory dolomite containing carbon bricks have long been in use in metallurgical vessels (in particular BOF converters) where the lining is subjected to slag attack and where high hot strength and high resistance of the refractories are desired and required. An adequate thermal expansion allowance or excessive rates of heating or cooling, spalling, wear and slag compositions has been the main factors that affects directly on the lining lifetime. The designers and operators have been considerably succeed to avoid the problems that results from the expansion by controlling of the heat / cooling rates. Although the problem of slag attacking has been studied by many researcher but it still needs much work to be solved.

Generally, the slag attack is mainly influenced by the basicity, iron oxide content, temperature, viscosity (physically) and bulk of slag. ${ }^{17)}$ Thus controlling the physical and chemical properties of the slag in its best condition is very important to prolong the lining life. Actually, in the steel industry, iron oxide content of the slag seems to be considered the main factor that affects on the lining. Therefore, a finding method to assess the slag attacking resistance of BOF refractories in the laboratory is very important. Numerous methods have been tried, and reasonable correlations were obtained with particular service conditions, but very few have been standardized and even less accepted for general use. The slagging under load test, which was developed by the Japanese workers, is one of the methods that can be considered suitable for the simulation of the industrial application of refractory. ${ }^{18)}$ In this method, combining hot compressive creep test and slagging test using crucible shaped refractory specimen and the deformation under load was measured at fixed temperature under a state when slag is filling the crucible shaped specimens.

The aim of the present work is to develop a new method to study the BOF slag attacking under load of tempered tarbonded Egyptian dolomite by tars with different contents of pitch. The effect of the slag with different compositions was also studied to determine the factors that control the attacking and to optimize the softening temperature of the studied mixtures under load.

\section{Experimental work}

\subsection{Starting materials}

Egyptian sintered dolomite and magnesite that used were supplied from Egyptian Iron and Steel Company (Helwan, Egypt). The average chemical composition of these materials (provided by supplier) is given in Table 1. The sintered dolomite used in the study is the local raw dolomite of Adabyia Formation South Suez Town that thermally treated at Helwan plant for the production of tar-bonded dolomite blocks.

The mineralogy of this material was extensively studied. ${ }^{19), 20)}$ It was almost composed mainly from free lime $(\mathrm{CaO})$, magnesia $(\mathrm{MgO})$ and small amounts of dicalcium ferrite $\left(2 \mathrm{CaO} \cdot \mathrm{Fe}_{2} \mathrm{O}_{3}\right)$ and tricalcium silicate $\left(3 \mathrm{CaO} \cdot \mathrm{SiO}_{2}\right)$.

Three coal tar samples I, II and III of different viscosity and carbon residue values were made up by mixing high carbon residue pitch with low naphthalene anthracene oil in variable proportion. A similar procedure of preparation of 
Table 1. Physical Properties and Chemical Analysis of Doloma Produced at Helwan Steel Plant

\begin{tabular}{|l|c|c|}
\hline Property & Sintered dolomite & Sintered magnesia \\
\hline Physical properties & & \\
\hline Apparent porosity, \% & 6.87 & \\
Bulk density, $\mathrm{g} / \mathrm{cm}^{3}$ & 2.96 & \\
& & \\
Chemical analysis & 1.25 & 3.94 \\
$\mathrm{SiO}_{2}, \%$ & & \\
$\mathrm{R}_{2} \mathrm{O}_{3}, \%$ & $5.33\left[\mathrm{Fe}_{2} \mathrm{O}_{3}: 5.10, \mathrm{Al}_{2} \mathrm{O}_{3}: 0.23\right]$ & $4.00\left[\mathrm{Fe}_{2} \mathrm{O}_{3}: 1.21, \mathrm{Al}_{2} \mathrm{O}_{3}: 2.79\right]$ \\
$\mathrm{CaO}, \%$ & 59.40 & 4.11 \\
$\mathrm{MgO}, \%$ & 33.44 & 87.94 \\
Loss on Ignition & 0.58 & 0.08 \\
\hline
\end{tabular}

Table 2. Physical Properties and Chemical Analysis of the Prepared for Tars (I), (II) and (III)

\begin{tabular}{|l|c|c|c|}
\hline Property & Tar (I) & Tar(II) & Tar (III) \\
\hline Specific gravity $\left(25 / 25^{\circ} \mathrm{C}\right.$ ) & 1.26 & 1.27 & 1.29 \\
Viscosity (standard viscometer, cup $10 \mathrm{~mm}, 60^{\circ} \mathrm{C}, 50$ & & & \\
ml), Sec & 22 & 55 & 165 \\
Naphthalene, \% & 124 & 1.02 & 0.62 \\
Pitch $\left(>360^{\circ} \mathrm{C}\right) \%$ & 76.20 & 80.1 & 88.06 \\
Water $(50 \mathrm{ml}$ Xylene $/ 50 \mathrm{ml}$ Benzene, $2 \mathrm{~h}) \%$ & nil & nil & nil \\
Distillation range: & & & \\
Up to $210^{\circ} \mathrm{C}, \%$ & 0.15 & 0.13 & 0.08 \\
$210-300^{\circ} \mathrm{C}, \%$ & 4.18 & 3.15 & 2.37 \\
$300-360^{\circ} \mathrm{C}, \%$ & 18.20 & 15.23 & 9.00 \\
Softening point of pitch, (Ball and Ring test), ${ }^{\circ} \mathrm{C}$ & 82 & 82 & 82 \\
Conradson Carbon-Residue test: & 39 & 43 & 47 \\
$\quad$ Residue on tar as received, \% & 50 & 50 & 50 \\
$\quad$ Residue on pitch as made, \% & & & \\
\hline
\end{tabular}

Table 3. Chemical Composition of the Slags Used in Slagging under Load Tests

\begin{tabular}{|l|c|c|c|}
\hline $\begin{array}{l}\text { Chemical } \\
\text { composition, } \\
\text { \% }\end{array}$ & BOF & Synthetic slag 1 & Synthetic slag 2 \\
\hline $\mathrm{SiO}_{2}$ & 7.5 & 7.8 & 7.84 \\
$\mathrm{FeO}$ & 0.52 & 24.01 & 21.76 \\
$\mathrm{Fe}_{2} \mathrm{O}_{3}$ & 26.30 & 1.35 & 2.55 \\
$\mathrm{Al}_{2} \mathrm{O}_{3}$ & 1.8 & 1.26 & 0.8 \\
$\mathrm{CaO}$ & 50.10 & 48.13 & 47.00 \\
$\mathrm{MgO}$ & 1.75 & 5.43 & 9.44 \\
$\mathrm{P}_{2} \mathrm{O}_{5}$ & 4.2 & 4.00 & 3.92 \\
$\mathrm{MnO}$ & 5.9 & 6.49 & 5.86 \\
$\mathrm{~S}$ & 0.6 & 0.35 & 0.35 \\
$\mathrm{C}$ & 0.90 & 0.40 & 0.40 \\
\hline
\end{tabular}

tar for the production of tar bonded dolomite blocks at Helwan plant was applied. The materials were supplied by ElNasr Coke Company (Helwan, Egypt). The analyses of the four prepared tar samples are conducted according to ASTM Standard procedure. ${ }^{21)}$ The data are tabulated in Table 2.

The slags of BOF that usually produced at Helwan plant and synthetic slag of different iron content and basicity specially prepared was used. The slag was crushed to powder of not more than $710 \mu \mathrm{m}$. Chemical analysis of the slags was presented in Table 3.

\subsection{Body mixes preparation}

Three batches were prepared from mixtures of sintered dolomite with tar/pitch (I), (II) and (III). Another two batches were prepared from sintered dolomite/tar/pitch (III) with $30 \%$ and $50 \%$ magnesite $(-0.09 \mathrm{~mm})$ respectively. The amount of tar added was $7.2 \%$. Dolomite or dolomite/ magnesite and tar were heated to $100^{\circ} \mathrm{C}$ before mixing. $40 \%$ coarse $(10-3 \mathrm{~mm})$ and $10 \%$ medium fractions (3-1 mm) were well mixed for $2 \mathrm{~min}$. Then some of tar was added and mixed for $5 \mathrm{~min}$ followed by the addition of the $50 \%$ fine fraction $(-0.1 \mathrm{~mm})$ and mixed for $5 \mathrm{~min}$. Then the rest of tar was added and the whole materials were mixed for $10 \mathrm{~min}$. The mixing was carried out in preheated con-
Table 4. Hydration Tendency of Exposed Tempered Tar-Bonded Dolomite and Dolomite Magnesite

\begin{tabular}{|l|c|}
\hline \multicolumn{1}{|c|}{ Type of test specimen } & $\begin{array}{l}\text { Time(days) before complete } \\
\text { collapsed of the exposed test } \\
\text { specimen }\end{array}$ \\
\hline Tar(I)-bonded dolomite & 15 \\
Tar(II)-bonded dolomite & 20 \\
Tar(III)-bonded dolomite & 34 \\
Tar(III)-bonded dolomite-30\% magnesite clinker & 39 \\
Tar(III)-bonded dolomite-50\% magnesite clinker & 44 \\
\hline
\end{tabular}

tainer (to the same temperature range). The tarred materials were kept in sealed tins overnight. Cylindrical sample briquettes of $5 \mathrm{~cm}$ diameter and $5 \mathrm{~cm}$ height were semi-dry formed under a pressure of $1300 \mathrm{~kg} / \mathrm{cm}^{2}$. Grain sizes of $40 \%$ coarse fraction $(10-3 \mathrm{~mm}), 10 \%$ medium fractions $(3-1 \mathrm{~mm})$ and $50 \%$ fine fraction $(-0.125 \mathrm{~mm})$, were selected on the basis of packing density measurements. The content of tar and its temperature was optimized according to previous study. ${ }^{22)}$

The moulded samples were tempered in closed oven in which the specimens were settled at $100^{\circ} \mathrm{C}$ for $1 \mathrm{~h}$. Then the temperature was raised up to $300^{\circ} \mathrm{C}$. The rate of heating up was $30-40^{\circ} \mathrm{C} / \mathrm{h}$. When $300^{\circ} \mathrm{C}$ was reached, the test specimens were left for at least $7 \mathrm{~h}$.

The hydration resistance was characterized by the exposure the test specimen to atmosphere till completely collapsed. The data obtained was tabulated in Table 4. The date presented that the hydration resistance increases with increasing the content of pitch and magnesia. This was rationalized in previous study. ${ }^{22)}$

\subsection{Slagging under load test}

Slagging under load tests in the present work was carried out according to the normal refractoriness under load standard test DIN (German Industrial Standards) NO. 1064. A crucible having a hole of $2 \mathrm{~cm}$ in diameter $\times 3 \mathrm{~cm}$ in depth was drilled in the central part of the tempered tar/pitch dolomite and tar/pitch dolomite-magnesite samples of $5 \mathrm{~cm}$ in diameter $\times 5 \mathrm{~cm}$ in height. The hole was filled by normal slag micropowder of BOF that usually produced at Helwan plant or synthetic slag specially prepared in the present work. The test piece was placed in central portion of the furnace on carbon plate on carbon support where the temperature surrounding the test piece is found in the belt of even temperature, and by adjusting the length of carbon rod by cutting as indicated in Fig. 1. The upper part of the test piece was covered by carbon disc and then carbon tube was placed on this disc. Different loads $\left(3.5,4\right.$ and $5 \mathrm{~kg} / \mathrm{cm}^{2}$ respectively) were applied on the upper part of the test piece. The temperature of the furnace was raised and adjusted via thermocouple: The heating speed was $5^{\circ} \mathrm{C} / \mathrm{min}$ to $1000^{\circ} \mathrm{C}$ and above. The temperature was soaked for one hour at each peak temperature of $1200^{\circ} \mathrm{C}, 1300^{\circ} \mathrm{C}, 1400^{\circ} \mathrm{C}$, $1500^{\circ} \mathrm{C}, 1600^{\circ} \mathrm{C}$ and $1700^{\circ} \mathrm{C}$. The variation of the height of the test piece at the end of hour was recorded.

\section{Results and discussions}

3.1 Influence of pitch content on load bearing capacity

The results of deformation of BOF slagged tempered tar/ pitch-bonded dolomite under load of $3.5 \mathrm{~kg} / \mathrm{cm}^{2}$ as a function of temperature and different pitch content is illustrated in Fig. 2. This figure shows that the measured dimensions of the tar/pitch-bonded dolomite specimens decrease with the increase of temperature. It is also clear that increasing the pitch content of used tar in the limits of the experimental work, generally, improve the refractoriness under load of the tar-bonded dolomite at a temperature range of $1200-1700^{\circ} \mathrm{C}$. This can be rationalized by the increase of the 


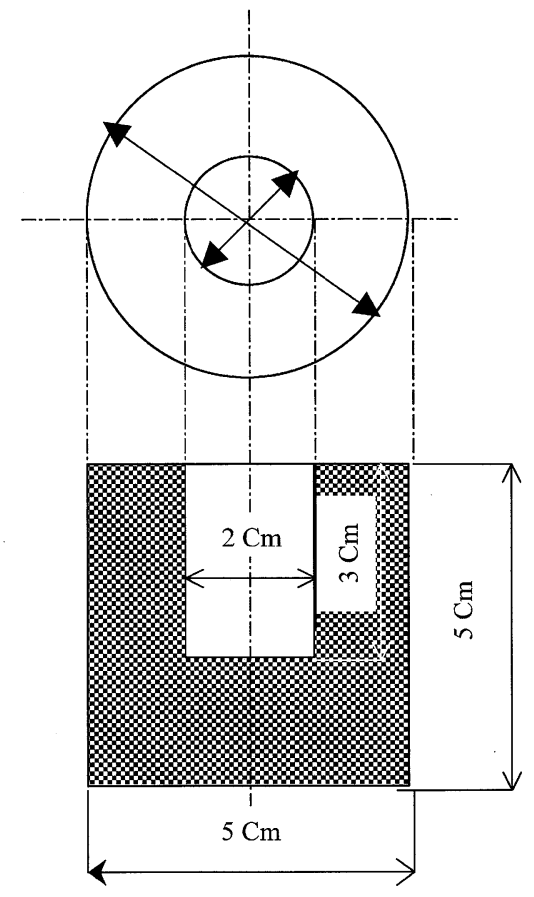

$\underline{A}$

Fig. 1. Dimension of the crucible-shaped specimen for slag under load test (A) and its assembly in the test furnace (B).

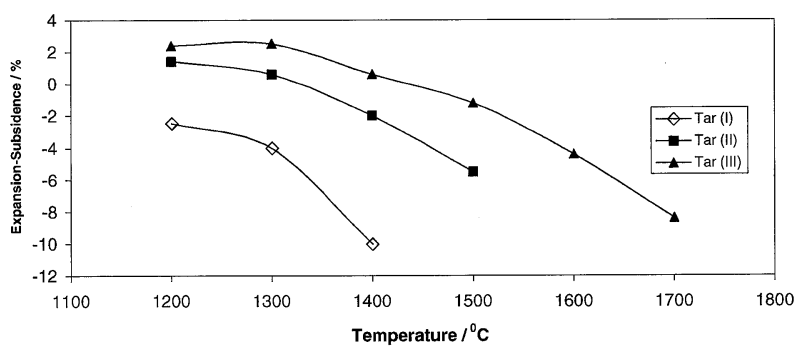

Fig. 2. Deformation of BOF slagged tempered different tar/pitchbonded dolomite bricks as a function of temperature under load 3.5 $\mathrm{kg} / \mathrm{cm}^{2}$.

content of the residual carbon that in turn increase the resistance of the specimen to the BOF slag attack and inhibit its penetration in the specimen. The lower content of residual carbon means a decreasing of the nonwettable materials content (e.g. carbon) that helps in limiting slag penetration past the carbon interface. ${ }^{23}$ ) Therefore the penetration of the slag to attack the specimen will be high leading to subsidence or shrinkage as viewing in the behavior of the specimens. This clear from the illustrated results as the tar/pitch (I), (II) and (III) -bonded dolomite specimens failed at 1500,1600 and $1700^{\circ} \mathrm{C}$, respectively. At the same time, the decrease of the expansion with increase temperature seems to be due to not only the temperature but also to the slag composition. The later is suggested to play the main role in this process. The high iron oxide content can consume considerable amount of residual carbon of the refractory in its reduction to iron or lower oxides. ${ }^{24}$ ) The lower oxides can also form with both calcium and magnesi-
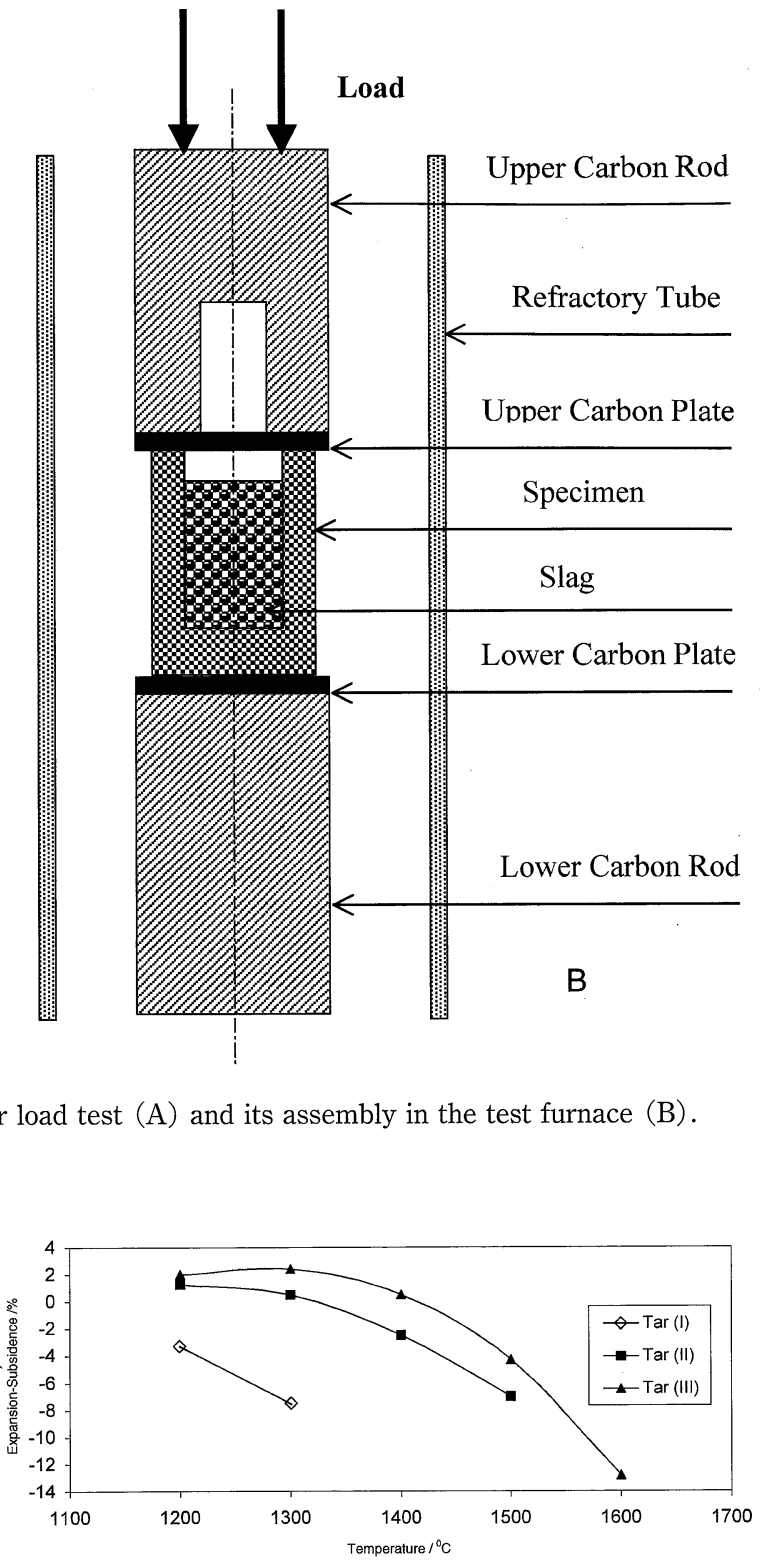

Fig. 3. Deformation of BOF slagged tempered different tar/pitch bonded dolomite bricks as a function of temperature under load $4 \mathrm{~kg} / \mathrm{cm}^{2}$.

um oxides calcium and magnesium ferrites with low melting temperature enhancing the decrease of the expansion. As reported the increasing of the temperature oxidize the carbon to carbon monoxide which creates a slightly position pore pressure in the specimen and make it more difficult for slag penetration. ${ }^{25)}$

With increasing the load over the specimen to $4 \mathrm{~kg} / \mathrm{cm}^{2}$, the specimen showed the same behavior but with higher values for shrinkage or subsidence and lower values for the expansion as shown in Fig. 3. The specimen also showed earlier failure in comparison with effect of the $3.5 \mathrm{~kg} / \mathrm{cm}^{2}$ as given in Table 5. The tar/pitch (I), (II) and (III)-bonded dolomite specimens were failed at lower temperature values; $1400^{\circ} \mathrm{C}$ after $10 \mathrm{~min}, 1600^{\circ} \mathrm{C}$ after $2 \mathrm{~min}$ and $1700^{\circ} \mathrm{C}$ after $2 \mathrm{~min}$, respectively. These results confirm the role of the carbon and the effect of load. This means that the increasing of the pitch content in tar led to increase in the content of the residual carbon, which in turn retard the slag at- 
Table 5. Failure Temperature and the Time of BOF Slagged Tar/ Pitch (I, II, and III)-Bonded Dolomite as a Function of Load Bearing Capacity

\begin{tabular}{|c|c|c|c|}
\hline $\begin{array}{c}\text { Load, } \\
\mathbf{k g} / \mathbf{c m}^{\mathbf{2}}\end{array}$ & $\begin{array}{c}\text { Tar/Pitch(Type)-bonded } \\
\text { Dolomite }\end{array}$ & $\begin{array}{c}\text { Failure } \\
\text { Temperature, }{ }^{\circ} \mathrm{C}\end{array}$ & $\begin{array}{c}\text { Time, } \\
\text { Min }\end{array}$ \\
\hline \multirow{3}{*}{3.5} & (I) & 1500 & 7 \\
\cline { 2 - 4 } & (II) & 1600 & 30 \\
\hline \multirow{3}{*}{4} & (III) & 1700 & No failure \\
\cline { 2 - 4 } & (I) & 1400 & 10 \\
\cline { 2 - 4 } & (II) & 1600 & 2 \\
\hline 5 & (III) & 1700 & 2 \\
\hline
\end{tabular}

tacking for the specimens. The results of the trial made for examining the effect of increasing the load to $5 \mathrm{~kg} / \mathrm{cm}^{2}$ for different specimen showed that only tar (III)-bonded dolomite can resist this load up to $1400^{\circ} \mathrm{C}$.

\subsection{Effect of the addition of Magnesia on load bearing} capacity

Figure 4 shows the effect of the additions of magnesia on deformation of BOF slagged tar/pitch (III)-bonded dolomite under load $4 \mathrm{~kg} / \mathrm{cm}^{2}$ as a function of temperature. The additions of $30 \%$ and $50 \%$ magnesia showed gradually decrease in the measured dimensions of the tar/pitch (D)bonded dolomite specimens as the temperature increases above $1300^{\circ} \mathrm{C}$ without failure. However, the subsidence or shrinkage decreased with increasing the content of the magnesia. The addition of magnesia will be accompanied by decreasing the amount of the free lime. These lime forms lime hydrates that readily dissolves in ferrites of the slag at a greater rate than magnesia. ${ }^{26)-28)}$ According to the phase diagram " $\mathrm{CaO}-\mathrm{MgO}-\mathrm{FeO}-\mathrm{SiO}_{2}$," the liquid phase in equilibrium with periclase contains relatively small amounts of $\mathrm{MgO}$ rise the liquidus temperatures very steeply toward the $\mathrm{MgO}$ apex within the primary phase volume of periclase. ${ }^{29)}$ Hence, The solubility of magnesia in these liquids (slag) will be relatively moderate even at high temperatures prevailing in steelmaking, and the fluxing action of magnesia by calcium-magnesium-iron silicate slags is moderate. The moderate amount of the iron oxide of the slag, on the other hand, readily forms a solid solution with periclase phase of the brick and also partially soluble in lime under strongly reducing conditions. In addition, the initial temperature of the liquid formation will be high. The addition of magnesia increases the density of the specimen and decreases its porosity.

These discussions can contribute in rationalization why the addition of magnesia decreased the shrinkage or subsidence and doesn't show failure with these ranges of temperatures.

As discussed, the heating of pitch-containing magnesia and calcia refractories in air develops a dense layer of calcia and magnesia. ${ }^{29)-34)}$ Since, the carbon produces a reducing condition in the specimen interior causing reduction of some magnesia to magnesia vapor, which migrates and reoxidize (deposits) in another region to form the magnesia-dense zone. Although calcia can develop a dense layer by the same mechanism like magnesia but $\mathrm{Ca}$ vapor reaches a position along the gradient when a solid $\mathrm{CaO}$ is stable form, while $\mathrm{Mg}$ species are still in the gas phase. So the $\mathrm{CaO}$ precipitate forming an intimate dense zone, essentially pure $\mathrm{CaO}$ containing towards the specimen surface. Therefore, formation of dense layer from the calcia on the surface of the specimen on the surface can easily dissolve in the ferrite slag leading to erosion and facilitating the slag to attack the samples. Therefore, the specimen without addition of magnesia failed as given in Table 6. While the formation of a dense layer from the magnesia interior the specimen protects the carbon from the oxidation and decreases the slag penetration.

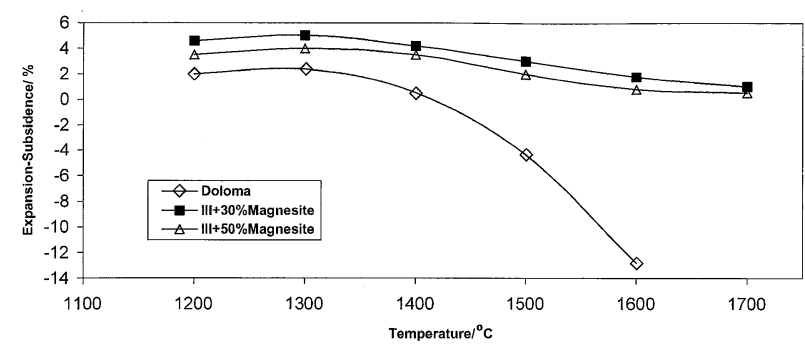

Fig. 4. Deformation of BOF slagged tempered tar/pitch(III)bonded dolomite-magnesite bricks as a function of temperature under load test of $4 \mathrm{~kg} / \mathrm{cm}^{2}$.

Table 6. Failure Temperature and the Time of BOF Slagged Tar/. pitch (III)-Bnded Dolomite with Different Content of Magnesia as a Function of Lload Bearing Capacity

\begin{tabular}{|c|c|c|c|}
\hline $\begin{array}{c}\text { Load, } \\
\mathbf{k g} / \mathbf{c m}^{2}\end{array}$ & $\begin{array}{c}\text { Magnesia content, } \\
\text { \% }\end{array}$ & $\begin{array}{c}\text { Failure } \\
\text { Temperature, }\end{array}{ }^{\circ} \mathrm{C}$ & $\begin{array}{c}\text { Time, } \\
\text { Min }\end{array}$ \\
\hline \multirow{3}{*}{4} & without & 1700 & 2 \\
\cline { 2 - 4 } & 30 & 1700 & No failure \\
\cline { 2 - 4 } & 50 & 1700 & No failure \\
\hline \multirow{3}{*}{5} & without & 1500 & 5 \\
\cline { 2 - 4 } & 30 & 1600 & 15 \\
\cline { 2 - 4 } & 50 & 1700 & No failure \\
\hline
\end{tabular}

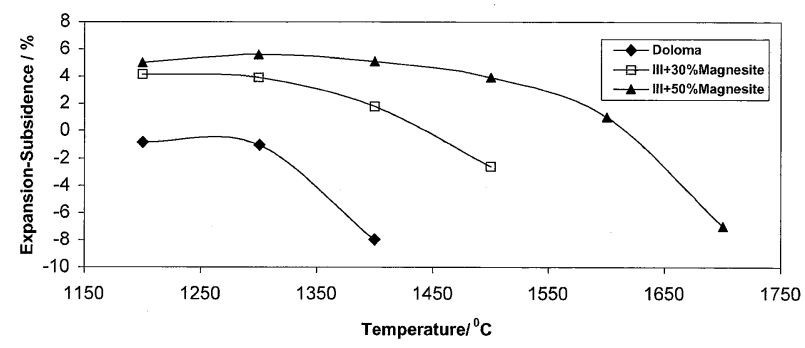

Fig. 5. Deformation of BOF slagged tempered tar/pitch(III)bonded dolomite-magnesite bricks as a function of temperature under load test of $5 \mathrm{~kg} / \mathrm{cm}^{2}$.

Thus, the tendency of the slag to penetrate or attack the sample decreased, consequently no failure happened with heating up $1700^{\circ} \mathrm{C}$ the temperature. Hence, the addition of magnesia give tar/pitch (III)-bonded dolomite excellent thermal conductivity properties so there is good heat flow the specimen inasmuch as this component increase the resistance of the brick to $\mathrm{BOF}$ slag attack.

With increasing the load to $5 \mathrm{~kg} / \mathrm{cm}^{2}$ as shown in Fig 5 , the specimen showed the same higher values for shrinkage or subsidence and lower values for the expansion. The tar/ pitch (III) with addition of $30 \%$ magnesia failed at $1600^{\circ} \mathrm{C}$ after $15 \mathrm{~min}$, however, no failure occur up to $1700^{\circ} \mathrm{C}$ for $1 \mathrm{~h}$ as given in Table 6 . Because of the increasing of the load with heating up enables the slag to overcome on the position of the pore pressure in the specimen that created from the formation of carbon monoxide during the process. In addition, it could expel the $\mathrm{Mg}$ vapor exterior of the specimen preventing it to form a dense layer from the $\mathrm{MgO}$ that protect the carbon from the oxidation. Therefore, the specimen showed failure with addition of 30 mass $\%$ magnesia. However, the increasing of the magnesia content to 50 mass \%, high thermal conductivity material, lead to formation of high refractoriness mineral phase that has the tendency to withstand the load. In addition, the $\mathrm{Mg}$ vapor that produced during the heating could be much and the load not 
enough to expel it out but it could assist it to redeposited forming a dense layer interior the specimen. For these reasons, the increasing of the content of magnesia to 30 mass\% doesn't show failure up to $1700^{\circ} \mathrm{C}$.

\subsection{Influence of slag composition}

The influence of the slag composition on deformation of tempered tar/pitch (III)-bonded Egyptian dolomite under load of $4 \mathrm{~kg} / \mathrm{cm}^{2}$ is showed in Fig. 6 . From the figure, it seems that, at relatively low temperature $\left(1250-1350^{\circ} \mathrm{C}\right)$, the effect of both the currently BOF and synthetic slags on the deformation tempered tar/pitch (III)-bonded Egyptian dolomite has the same behaviour. However, the increase of the temperature leads to different degrees of expansion (i.e. increase of subsidence) of the refractory. The general behaviour of the tempered tar/pitch (III)-bonded Egyptian dolomite using all types of slags studied shows a decrease of the expansion (i.e., increase of subsidence) with temperature increase up to $1700^{\circ} \mathrm{C}$. The least effect of slag on the refractory can be remarked when using slag 2 . This effect can be due mainly to the slag composition. The increasing of the content of $\mathrm{MgO}$ in the slag to 9 mass\% changes the basicity compared with the BOF slag, as the basicity will increase from 7.15 to 10.03 , if calculated as $\mathrm{B}_{5}=\mathrm{CaO}+\mathrm{MgO} /$ $\mathrm{SiO}_{2},{ }^{35)}$ and from 3.053 to 8.01 , if calculated as $\mathrm{B}=\mathrm{CaO}+$ $\mathrm{MgO}+\mathrm{FeO}+\mathrm{MnO} / \mathrm{SiO}_{2}+\mathrm{Fe}_{2} \mathrm{O}_{3}+\mathrm{Al}_{2} \mathrm{O}_{3}+\mathrm{P}_{2} \mathrm{O}_{5} \cdot{ }^{36)}$ At the same time, increasing the $\mathrm{MgO}$ hinders the dissolution of the $\mathrm{MgO}$ of the refractory in the molten slag. Both effects lead to a significant improving in the resistance to the slag attack under load. This is clear in the temperature values and time at which the refractory specimens failed as shown in Table 7, as the specimen failed at $1700^{\circ} \mathrm{C}$ after 2 min by in presence of the currently produced BOF slag. As reported, ${ }^{35)}$ the isothermal sections through the ternary system of the quaternary $\mathrm{CaO}-\mathrm{MgO}-\mathrm{FeO}-\mathrm{SiO}_{2}$ revealed that the $\mathrm{CaO}-\mathrm{FeO}-\mathrm{SiO}_{2}$ is characterized by an extensive all-liquid field and a large $\mathrm{Ca}_{2} \mathrm{SiO}_{4}$ stability area extending into this field. In this system, the fluidized oxides are $\mathrm{SiO}_{2}$ and $\mathrm{FeO}$ resulting in the large liquid area. This decreases the slag viscosity with increasing the temperature and in turns leads to facilitate its penetration to the refractory specimen. However, increasing the $\mathrm{MgO}$ content of the slag hinders the dissolution of $\mathrm{MgO}$ of the refractory in the molten slag. At the same time increasing the basicity by increasing $\mathrm{MgO}$

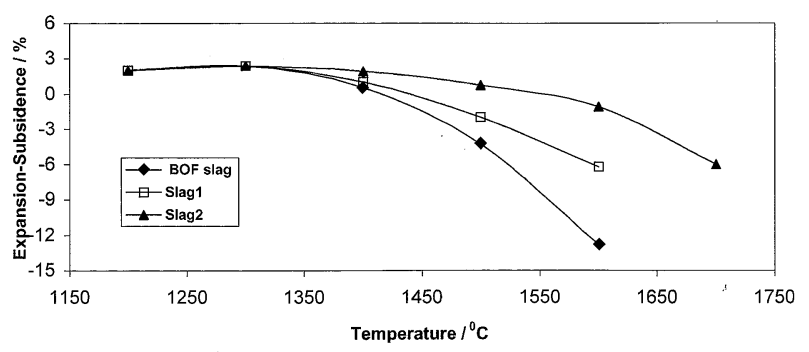

Fig. 6. Deformation of BOF and synthetic slagged tempered tar/ pitch (III)-bonded dolomite bricks as a function of temperature under load test of $4 \mathrm{~kg} / \mathrm{cm}^{2}$.

Table 7. Failure Temperature and the Time of BOF Slagged Tar/ pitch (III)-Bonded Dolomite under Load of $4 \mathrm{~kg} / \mathrm{cm}^{2}$ as a Function the Slag Composition

\begin{tabular}{|c|c|c|}
\hline Slag Type & Failure Temperature, ${ }^{\circ} \mathrm{C}$ & $\begin{array}{c}\text { Time, } \\
\text { Min }\end{array}$ \\
\hline Currently produced BOF & 1700 & 2 \\
\hline Synthetic $(1)$ & 1700 & 40 \\
\hline Synthetic (2) & 1700 & No failure \\
\hline
\end{tabular}

content of the slag decreases all the liquid area at the $\mathrm{FeO}$ apex, and extensive formation of solid solution between $\mathrm{FeO}$ and $\mathrm{MgO}$ in the $\mathrm{CaO}-\mathrm{FeO}-\mathrm{MgO}$ system $^{35)}$ occurs and increases the tendency of formation of highly refractory phases like ( $\left.\mathrm{Mg}, \mathrm{Fe}, \mathrm{Mn}) \mathrm{O},{ }^{37}\right)$ which increases the viscosity of the slag and decreases its penetration to refractory specimen and consequently hinders its attack by the slag.

\section{Conclusion}

It can be concluded from the above results that the tempered tar/pitch (III) of high pitch content can be considered as beneficial type for manufacture of the tempered tar/pitch (III)-bonded Egyptian dolomite because it retarded the BOF slag attack. Tempered tar/pitch (III)-bonded Egyptian dolomite also can be recommended for lining the converter under load less than $4 \mathrm{~kg} / \mathrm{cm}^{2}$. The Addition of $30 \%$ magnesia for tempered tar/pitch(III) Egyptian dolomite can prolong the application of these types under load reach 4 and $5 \mathrm{~kg} / \mathrm{cm}^{2}$ if the $50 \%$ magnesia added. This study confirms that the content of the iron oxide of the slag is the responsible for the attacking of refractories and if the iron oxide is low, the resistance of the specimen will be high. This test can be used as fast criteria for the determination of the resistance of the refractories for slag attacking. This can be considered as beneficial test because it simulates the application of the refractories in the furnace. $T$ the same time, it provides the manufacturer by valuable data about the behavior of the refractory material attacked by slag under load.

Acknowledgement The authors would like to thank the following for their valuable comments and discussion: Dr. Bahgat ElAnadouli, Prof. of Physical Chemistry, Chemistry Dept. Faculty of Science, Cairo University and Dr. Michael L. Mishreky, Prof. of Metallurgy, Steel \& Ferroalloys Dept. CMRDI.

\section{References}

1) Kasal, K., Nippon Steel Technical Report, [61], April, 83-89 (1994)

2) Zhong, X.-C., Interceram, 44, 105-10 (1995).

3) Hayashi, T., Transaction ISIJ, 21, 607-17 (1981)

4) Zoglmeyr, G. and Komei, D., Interceram, 40, 81-89 (1991).

5) Xing, S. and Liu, J., China's Refract., 2[4], 3-11 (1993).

6) Peaslee, K. D., Smith, J. D. and Fang, H., Electric Furnace Conference Proceedings (1998) pp. 255-66.

7) Koltermann, M. and Bartha, P., Proceedings of International Symposium on Refractories: Refractory Raw Materials \& High Temperature Performance Refractory Products, August (1988) pp. 333-54.

8) Chatillon, J. H. and Schmidt-Whitley, R. D., Proceedings of International Symposium on Refractories: Refractory raw Materials \& High Temperature Performance Refractory Products, August (1988) pp. 433-51.

9) Wenclawiak, C. and Malker, G., Proceedings of International Symposium on Refractories: Refractory Raw Materials \& High Temperature Performance Refractory Products, $\mathrm{Au}-$ gust (1988) pp. 452-66.

10) Shiping, H. and Yulian, L., Proceedings of International Symposium on Refractories: Refractory Raw Materials \& High Temperature Performance Refractory Products, August (1988) pp. 467-74.

11) Scheerer, P. E. and Stendera, J. W., Unitecr'95 Congress. Proc. Unified Int. Tech. Conf. On Refractories: 4 th Biennial Worldwide Conf. on Refractories, "Global Development of Refractories," Vol. 3, 17-24, Kyoto, November 19-22 (1995).

12) Rigaud, M., Bombard, P., Li, X. and Gueoult, B., Unticr'93 Congress Refractories for the New World Economy. Proc. Conf. Sao Paulo, Paulo, 31 October-3 November (1993) pp. 360-71.

13) Nabeshima, S., Suzuki, H., Imaiida, T., Kanatani, T. and Kuga, M., "Improvement in Refractory of Top and Bottom 
converter (K-Bop) at Chiba No. 1 Steelmaking Shop," Unitecr'95 Congress. Proc. Unified Int. Tech. on Refractories: 4 th Biennial Worldwide Conf. on Refractories, "Global Development of Refractories," Vol. 3, Kyoto, November 19-22 (1995) pp. 25-32.

14) Kappmyer, K. K. and Hubble, D. H., "High Temperature Oxides," Ed. Alper, A. M., Academic Press, N. Y. and London, Part I (1970) pp. 1-76.

15) Chester, J. H., "Product \& Properties," Iron \& Steel Institute, London (1973) pp. 201-07.

16) Routscka, G., "The 27 th International Colloquia on Refractories: Refractories for Steelmaking Converters," Aachen, October (1984), cfi/Ber. DKG, 62, 51 (1985).

17) Wakushima, S., Iihama, U. and Sato, K., The Iron \& Steel Institute, London, Publication, 98, 97 (1966).

18) Ohba, H. and Sugita, K., J. Ceram. Assoc. Japan, 71, 163-68 (1963).

19) Serry, M. A., Abdallah, M. A., Attia, A. S., Khalifa, M. G. and Selim, M. H., Bulletin TIMS, 57, 1-11 (1991).

20) Serry, M. A., Abdallah, M. A., Attia, A. S., Khalifa, M. G. and Selim, M. H., Bulletin TIMS, 57, 12-22 (1991).

21) A.S.T.M. Standards, Parts 15, 1974 (21).

22) El-Sherif, A. A., "Efficiency of the Oxygen Steel Converter Lining and Proposed Modifications to Increase its Service Life at Helwan Steel Works," Ph. D, Chemistry Department, Faculty of Science, Cairo University (1979).

23) Brenzy, R. and Semler, C. E., J. Am. Ceram. Soc., 67, 480-83 (1984).

24) Halm, L., J. Br. Ceram. Soc., 7, 42-46 (1970).
25) Baker, B. H., Breizny, B. and Shultz, R. L., Am. Ceram. Soc. Bull., 55, 649-54 (1976)

26) Spencer, D. R. E., Trans J. Br. Ceram., 71, 123-34 (1972).

27) Brendi, T., Heynert, G., Kahlhofer, G., Konig, G. and Wilms, E., The International Conference on The Science and Technology of Iron and Steel, Tokyo (1970).

28) Konig, G., Refractories J., April, 5-11 (1973).

29) Ricker, R. W., "Phase Equilibrium in the Quaternary System $\mathrm{CaO}-\mathrm{MgO}-\mathrm{FeO}-\mathrm{SiO}_{2}$, " Ph. D. Dissertation, The Pennsylvania State University (1952).

30) Brenzy, B. and Landy, R. A., Trans J. Br. Ceram., 71, 163-70 (1972).

31) Carniglia, S. C., Am. Ceram. Soc. Bull., 52, 160-65 (1973).

32) Leonard, R. J. and Herron, R. H., J. Am. Ceram. Soc., 55, 1-6 (1972).

33) Baker, B. H., Brezny, B. and Shultz, R. L., Am. Ceram. Soc Bull., 54, 665-66 (1975).

34) Baker, B. H., Brezny, B. H. and Shultz, R. L., Am. Ceram. Soc. Bull., 55, 649 (1976).

35) Pretorius, E. B. and Carlisle, R. C., "Foamy Slag Fundamentals and their Practical Application to Electric Furnace Steelmaking," Electric furnace Conference Proceedings (1998) pp. 275-92

36) Ward, R. G., "An Introduction to the Physical Chemistry of Iron \& Steel Making," Edward Arnold ISBN: 07131-29358, London, (1972) pp. 42-44.

37) Wanibe, Y., Shimoda, T., Ito, K. and Sakao, H., Transactions ISIJ, 23, 608-17 (1983). 